\title{
Diagnostic performance of CMR and transthoracic echocardiography in clinical evaluation of cardiac masses with histopathological correlation
}

\author{
Rima D Patel ${ }^{1 *}$, Ruth P Lim², Muhamed Saric ${ }^{1}$, Ambika Nayarr', James Babb¹, Leon Axel', Iryna Lobach', \\ Monvadi B Srichai ${ }^{1}$
}

From 16th Annual SCMR Scientific Sessions

San Francisco, CA, USA. 31 January - 3 February 2013

\section{Background}

Echocardiography is the preferred initial imaging method for assessment of cardiac masses. However, CMR, with its excellent tissue characterization and wide field of view, can provide unique information in the evaluation of cardiac masses. Our objective was to identify CMR and echocardiographic parameters that predict the presence of tumor or malignancy in biopsy proven cardiac masses and to assess the potential added value of CMR to echocardiography in the evaluation of cardiac masses.

\section{Methods}

We retrospectively identified 50 patients $(50 \%$ male, mean age $46 \pm 17$ years) referred for CMR evaluation of cardiac mass who underwent biopsy or resection with histopathological diagnosis. Echocardiography was performed prior to CMR in 44/50 (88\%) of the cases. Echocardiographic and CMR characteristics of the mass were evaluated for their predictive value in distinguishing tumor versus non-tumor and malignant versus non-malignant masses based on histopathology as the gold standard. Tumors were classified as any benign or malignant (primary or metastatic) neoplasm found in or around the heart while non-tumors were classified as any other mass (eg, thrombus) found in this area.Binary logistic regression and ROC curves were used to assess the diagnostic utility of these imaging characteristics alone and in combination for prediction of tumor or malignancy. Wilcoxon rank-sum test was used to compare the number of times a correct pathologic diagnosis was provided by each imaging study.

\section{Results}

The diagnostic performance of echocardiography and CMR parameters found to be significantly predictive of tumor and malignancy on pathology are depicted in the table. A diagnostic model incorporating the aforementioned parameters on echocardiography and CMR found no added value of CMR to echo in the diagnosis of malignant versus non-malignant masses $(\mathrm{AUC}=.928$ vs $\mathrm{AUC}=.891, \mathrm{p}=0.4405)$. In the 44 cases with both imaging studies, CMR provided significantly more correct pathologic diagnoses compared to echocardiography ( $77 \%$ vs $43 \%, \mathrm{p}<0.0001$ ).

\section{Conclusions}

Although no single or combination of CMR parameters demonstrated significantly improved performance for diagnosing tumor or malignancy over echocardiography, CMR can provide useful information on the underlying histopathologic diagnosis compared to echocardiography alone.

${ }^{1}$ Medicine, NYU School of Medicine, New York, NY, USA

Full list of author information is available at the end of the article

(C) 2013 Patel et al; licensee BioMed Central Ltd. This is an Open Access article distributed under the terms of the Creative Commons Attribution License (http://creativecommons.org/licenses/by/2.0), which permits unrestricted use, distribution, and reproduction in any medium, provided the original work is properly cited. 
Table 1 Diagnostic performance of significant echocardiography and CMR parameters for the detection of malignancy and tumor on pathology

\begin{tabular}{|c|c|c|c|c|c|}
\hline & Accuracy & Sensitivity & Specificity & PPV & NPV \\
\hline \multicolumn{6}{|c|}{ Echocardiography } \\
\hline \multicolumn{6}{|l|}{ Tumor $(n=31)$} \\
\hline 1. Location outside the right atrium & $72.7 \%(32 / 44)$ & $71.0 \%(22 / 31)$ & $76.9 \%(10 / 13)$ & $88.0 \%(22 / 25)$ & $52.6 \%(10 / 19)$ \\
\hline 2. Location outside the atria and ventricles & $50.0 \%(22 / 44)$ & $29.0 \%(9 / 31)$ & $100 \%(13 / 13)$ & $100 \%(9 / 9)$ & $37.1 \%(13 / 35)$ \\
\hline \multicolumn{6}{|l|}{ Malignant Tumor $(n=17)$} \\
\hline 1. Location outside the atria and ventricles & $77.3 \%(34 / 44)$ & $47.1 \%(8 / 17)$ & $96.3 \%(26 / 27)$ & $88.9 \%(8 / 9)$ & $74.3 \%(26 / 35)$ \\
\hline 2. Non-Mobility & $72.7 \%(32 / 44)$ & $82.5 \%(14 / 17)$ & $66.7 \%(18 / 27)$ & $60.9 \%(14 / 23)$ & $85.7 \%(18 / 21)$ \\
\hline 3. Pericardial effusion & $75.0 \%(33 / 44)$ & $52.9 \%(9 / 17)$ & $88.9 \%(24 / 27)$ & $75.0 \%(9 / 12)$ & $75.0 \%(24 / 32)$ \\
\hline \multicolumn{6}{|c|}{$C M R$} \\
\hline \multicolumn{6}{|l|}{ Tumor $(n=35)$} \\
\hline 1. Location outside the right atrium & $72.0 \%(36 / 50)$ & $77.1 \%(27 / 35)$ & $60.0 \%(9 / 15)$ & $81.8 \%(27 / 33)$ & $52.9 \%(9 / 17)$ \\
\hline 2. T2 Hyperintensity or Mixed Pattern & $76.0 \%(38 / 50)$ & $88.6 \%(31 / 35)$ & $46.7 \%(7 / 15)$ & $79.5 \%(31 / 39)$ & $63.6 \%(7 / 11)$ \\
\hline 3. Contrast Enhancement on First Pass & $86.0 \%(43 / 50)$ & $82.9 \%(29 / 35)$ & $93.3 \%(14 / 15)$ & $96.7 \%(29 / 30)$ & $70.0 \%(14 / 20)$ \\
\hline 4. Late Gadolinium Enhancement & $86.0 \%(43 / 50)$ & $85.7 \%(30 / 35)$ & $86.7 \%(13 / 15)$ & $93.8 \%(30 / 32)$ & $72.2 \%(13 / 18)$ \\
\hline \multicolumn{6}{|l|}{ Malignant Tumor $(n=21)$} \\
\hline 1. Location outside the atria and ventricles & $76.0 \%(38 / 50)$ & $61.9 \%(13 / 21)$ & $86.2 \%(25 / 29)$ & $76.5 \%(13 / 17)$ & $75.8 \%(25 / 33)$ \\
\hline 2. Non-Mobility & $78.0 \%(39 / 50)$ & $95.2 \%(20 / 21)$ & $65.5 \%(19 / 29)$ & $66.7 \%(20 / 30)$ & $95.0 \%(19 / 20)$ \\
\hline 3. Contrast Enhancement on First Pass & $70.0 \%(35 / 50)$ & $85.7 \%(18 / 21)$ & $58.6 \%(17 / 29)$ & $60.0 \%(18 / 30)$ & $85.0 \%(17 / 20)$ \\
\hline 4. Late Gadolinium Enhancement & $66.0 \%(33 / 50)$ & $85.7 \%(18 / 21)$ & $51.7 \%(15 / 29)$ & $56.3 \%(18 / 32)$ & $83.3 \%(15 / 18)$ \\
\hline 5. Myocardial Invasion & $72.0 \%(36 / 50)$ & $33.3 \%(7 / 21)$ & $100 \%(29 / 29)$ & $100 \%(7 / 7)$ & $67.4 \%(29 / 43)$ \\
\hline 6. Pericardial Effusion & $76.0 \%(38 / 50)$ & $47.6 \%(10 / 21)$ & $96.6 \%(28 / 29)$ & $90.9 \%(10 / 11)$ & $71.8 \%(28 / 39)$ \\
\hline
\end{tabular}

\section{Funding}

NYU School of Medicine

\section{Author details}

${ }^{1}$ Medicine, NYU School of Medicine, New York, NY, USA. ${ }^{2}$ Radiology, Austin

Health, Melbourne, VIC, Australia.

Published: 30 January 2013

doi:10.1186/1532-429X-15-S1-P59

Cite this article as: Patel et al:: Diagnostic performance of CMR and

transthoracic echocardiography in clinical evaluation of cardiac masses

with histopathological correlation. Journal of Cardiovascular Magnetic

Resonance 2013 15(Suppl 1):P59.

\section{Submit your next manuscript to BioMed Central} and take full advantage of:

- Convenient online submission

- Thorough peer review

- No space constraints or color figure charges

- Immediate publication on acceptance

- Inclusion in PubMed, CAS, Scopus and Google Scholar

- Research which is freely available for redistribution

Submit your manuscript at www.biomedcentral.com/submit
C Biomed Central 